\title{
CAN A VICTOR FORCE THE VANQUISHED TO PAY? FRANCE UNDER THE NAZI BOOT
}

\begin{abstract}
$\underline{\text { ABSTRACT }}$
Based on the failure of the post-World War I German reparations, it is commonly assumed that little or no payment can be coerced from a defeated opponent. However, occupation charges paid by France to Nazi Germany between 1940 and 1944 represent one of the largest recorded international transfers and contributed significantly to financing the overall German war effort. This case study uses a neoclassical growth model that incorporates essential features of the occupied economy and the postwar stabilization to assess the welfare costs of the policies that managed the payments to Germany. Surprisingly, the methods used to make these transfers closely resembled the techniques employed by contemporary belligerents. Occupation payments required a 16 percent reduction of consumption for twenty years, with the draft of labor to Germany and wage and price controls adding substantially to this burden. France's postwar debt overhang would have demanded large budget surpluses; but inflation, which erupted after Liberation, reduced the debt well below its steady state level. The Marshall Plan played only a modest direct role, while international credits helped to substantially lower the nation's burden.

JEL No. E1, E6, N1, and N4.

\author{
Filippo Occhino \\ Kim Oosterlinck \\ and \\ Eugene N. White
}

June 2006

The authors are respectively Assistant Professor of Economics at Rutgers University, New Brunswick, NJ, Assistant Professor at the Solvay Business School, Faculté des Sciences Sociales, Politiques et Économiques, Université Libre de Bruxelles, and Professor of Economics at Rutgers University, New Brunswick and Research Associate of the National Bureau of Economic Research. A preliminary version of this paper was presented at the Universitat Pompeu Fabra, University of California-Berkeley, New York University, the 2005 Economic History Association meetings and the NBER National Security Working Group. Comments from seminar participants are gratefully acknowledged.
\end{abstract}


"[Les allemands] ne nous ont rien enlevé de vive force; ils ont toujours tout acheté correctement; mais ils nous ont tout payé avec de l'argent qu'ils nous avaient volé."1

(Arnoult, 1959)

War finance has been studied by examining how available domestic resources are used by belligerents (Friedman, 1952, Ohanian, 1997). But, relatively little attention has been given to what defeated nations have been compelled to deliver to a victor. Based on the failure of Germany to pay its post-World War I reparations, conventional wisdom generally doubts that reparations or occupation charges are feasible in spite of the fact that they were common and often successful (White, 2001). In this paper, we examine perhaps the most successful case where the collapse of the French Third Republic left Hitler's Germany in control of a nearly equally powerful industrial economy. To finance its continuing war on other fronts, Germany secured a massive and, perhaps, unparalleled transfer of resources from France. Once they determined the occupation payments, the Germans left the French to decide how to raise the funds and contend with passive and active resistance from the population. This paper analyzes the policies employed by the collaborating government in Vichy to supply resources to the Nazi war machine, measuring the welfare costs of wartime programs and postwar stabilization plans and assaying the reasons for their choices.

Although the outlines of Vichy's fiscal and financial policies are generally known (Milward, 1970 and Margairaz and Bloch-Lainé, 1991), the short- and long-term effects of transferring over a quarter of annual GDP are not well understood. After comparing the magnitude of Vichy's payment to other episodes of reparations and war finance, we examine how it was funded and employ a neoclassical growth model to assess both wartime and postwar policies. We find that the burden imposed on the French economy caused it to shrink at a rapid pace, severely curtailing consumption and creating large debt and monetary overhangs, using policies and economic controls that were familiar to the belligerent powers in two World Wars. Although Vichy intended to manage the postwar debt burden with higher tax rates, these funded the new welfare state while rapid inflation slashed the real value of the debt.

\footnotetext{
1 "The Germans never seized anything by brute force; they always paid properly, but they paid with the money that they stole from us." While financial transfers were the most important element in German exploitation, Arnoult, Inspecteur Général des Finances, overlooks the looting immediately after the French defeat that Hermann Göring gleefully promoted.
} 


\section{The Magnitude of Vichy's Payments}

During World War II, the French economy became a vital part of the German war machine. The systematic exploitation of occupied countries provided important contributions to the Nazi state, aiding prosecution of the war and social peace at home. Table 1 shows the total payments made to Germany during its occupation of France. Seizures and requisitions, for which Vichy did not provide compensation to the victims, are excluded. ${ }^{2}$ Even though the measure of GDP is fragile and an underestimate because of the substantial black market, the total resources extracted by the Nazis is stunning. In the partial first year of occupation, nearly 20 percent of GDP was transferred, rising to well over a third of GDP in 1941 and 1942. The German defeat at Stalingrad led to complete mobilization and a higher level of exploitation in 1943 and 1944.

How should the size of these payments be viewed? Some idea of their magnitude can be assessed with two comparisons, the first relative to other war reparations and the second relative to the cost of war for belligerents. Defeat in 1940 was the third French loss in a modern war where occupation costs or reparations were imposed. After Napoleon's defeat at Waterloo and after the Franco-Prussian war, France was forced to pay reparations for occupation and the cost of the war in 1815 and 1871. Table 2 shows

the size and burden of these reparations. For the defeats of 1815 and 1871, the initial estimates of reparations are shown as percentage of one year's GDP.

Table 1

French Payments to Germany, 1940-1944

\begin{tabular}{|c|c|c|c|}
\hline & $\begin{array}{c}\text { French GDP } \\
\text { (FF billions) }\end{array}$ & $\begin{array}{c}\text { Occupation Costs } \\
\text { (FF Billions) }\end{array}$ & $\begin{array}{c}\text { Costs as a } \\
\text { Share of GDP } \\
\text { (percent) }\end{array}$ \\
\hline 1939 & 433 & & 19.5 \\
\hline 1940 & 419 & 81.6 & 36.8 \\
\hline 1941 & 392 & 144.3 & 36.9 \\
\hline 1942 & 424 & 156.7 & 55.5 \\
\hline 1943 & 493 & 273.6 & 27.9 \\
\hline 1944 & 739 & 206.3 & \\
\hline
\end{tabular}

Source: Carré, Dubois and Malinvaud (1972) provide the GDP data, Milward (1970), p. 271 gives the French payments to Germany.

\footnotetext{
${ }^{2}$ Milward (1970, pp. 82-3) estimates that German booty from France for 1940-1944 totaled 154 billion 1938 francs, of which 52.4 billion francs were military equipment. Most of this loot was seized in 1940, and more systematic policies of exploitation were deployed afterwards.
} 
Another measure of the burden assumes that reparations were financed wholly by foreign loans so that the burden becomes the debt service (Cohen 1985). ${ }^{3}$ Although the burdens in terms of one year's GDP are high, the foreign debt service imposes a more modest burden, which is optimal in the sense that it smoothes the path of consumption (Obstfeld and Rogoff, 1995). The 1815 and 1871 reparations were paid in full and ahead of schedule by the French government, borrowing partly from abroad. The postwarWorld War I German reparations were set much higher than earlier French reparations. ${ }^{4}$ However, Germany did not meet its reparations obligations. Given that Weimar Germany borrowed more additional funds than it repaid, the effect was to reverse reparations, raising income and consumption (Schuker, 1988).

Table 2

A Comparison of War Reparations

\begin{tabular}{|l|l|c|c|}
\hline & \multicolumn{1}{|c|}{$\begin{array}{c}\text { Indemnities } \\
\text { (billions) }\end{array}$} & $\begin{array}{c}\text { Percent of } \\
\text { One Year's } \\
\text { GDP }\end{array}$ & $\begin{array}{c}\text { Share of Debt } \\
\text { Service to } \\
\text { GDP }\end{array}$ \\
\hline France 1815-1819 & FF 1.65 to 1.95 & 18 to 21 & 1.2 to 1.4 \\
\hline France 1871 & FF 5.0 & 25 & 0.7 \\
\hline Germany 1923-1931 & DM 50 & 83 & 2.5 \\
\hline Vichy 1940-44 & FF 479 & 111 & 2.6 \\
\hline
\end{tabular}

Source: White (2001), Klug (1990) and Table 1.

Unlike previous reparations, delivered at the end of hostilities, the occupation costs imposed on defeated France in 1940 were open-ended; Hitler was adamant that he would only consider a peace treaty once the war was over. For Vichy, the figure for French reparations is the total sum of reparations paid over the years of occupation; 479 billion French francs is the sum of the real value of the payments. ${ }^{5}$ The base year for comparing the indemnity to GDP and tax revenues is 1939, a year of relatively high employment; its use reduces the burden compared to the war years when national income was lower. Favorable conditions, a long-term French growth rate of 2 percent and an interest rate of 4.4 percent---the same as used for Germany---are employed here and impart a downward bias to emphasize the minimum magnitude of the burden. In contrast

\footnotetext{
${ }^{3}$ The burden here is $b=(r-n) D /(1+n)$ GDP where $r$ is the interest rate, $n$ is the growth rate and $D$ is the total debt.

${ }^{4}$ The Allied Reparations Commission set German reparations at 132 billion gold marks in May 1921. Reparations bonds were divided into three segments A, B, and C. The A and B bonds were worth 50 billion marks, but most experts believed that the $C$ bonds would never be issued. See Schuker (1988).

5 INSEE's (1966, Tableaux XXVIII, p. 405) retail price index is used to deflate Vichy's indemnities. These are official prices and probably understate inflation. The official wholesale prices show even less sign of inflation and hence they were not used.
} 
to 1815 or 1871 or post-World War I Germany, Vichy had no access to outside capital markets and hence did not have the option to finance its obligations with foreign loans, but as a measure of size, potential debt service reveals that France's burden at minimum matched Germany's. Of course, France made these payments; Germany did not. As will be seen, the methods of payment proved "crushing," reducing consumption far more than 2.6 percent.

Table 3

A Comparison of War Finance

\begin{tabular}{|l|c|c|c|c|}
\hline & $\begin{array}{c}\text { U.S. World } \\
\text { War I } \\
\text { March 1917- } \\
\text { May 1919 }\end{array}$ & $\begin{array}{c}\text { U. S. } \\
\text { World } \\
\text { War II }\end{array}$ & $\begin{array}{c}\text { France } \\
\text { World } \\
\text { War I }\end{array}$ & $\begin{array}{c}\text { Vichy } \\
\text { France } \\
1940- \\
1944\end{array}$ \\
\hline $\begin{array}{l}\text { Total Expenditure as Share } \\
\text { of Pre-War GDP }\end{array}$ & 43 & 188 & 251 & 111 \\
\hline Share Financed by Taxes & 21 & 48 & 4 & 30 \\
\hline Share Financed by Debt & 70 & 31 & 83 & 36 \\
\hline Share Financed by Money & 9 & 21 & 13 & 34 \\
\hline
\end{tabular}

Sources: Friedman and Schwartz (1963), Fisk (1922), Ferguson (1998), Goldin (1980), INSEE (1966), Patat and Lutfalla (1990), Toutain (1997).

Vichy's methods of financing occupation payments may also be compared to French finance during World War I, when she had access to foreign markets, and to American finance during both World Wars, which was dependent on domestic finance. Occupation finance for 1940-1944 differs considerably from Republican France's financing of World War I, where most expenditure was covered by debt issues. Although the American participation in World War I only began in 1917 and her total expenditures relative to GDP were less, the pattern of financing is similar to French finance in the Great War. The strongest resemblance is between Vichy finance and the United States in World War II, although the United States was less reliant on money creation, utilizing taxes more heavily. The similarity is strengthened by the fact that both Nazi-occupied France and the arsenal of democracy used wage and price controls, rationing and financial repression. A signal difference is that the economy of Vichy France shrank, while the United States had a robust growth of output.

\section{The Occupation and German Demands}

Blitzkrieg against France began on May 10, 1940. Its spectacular success led to the resignation of the French government and the appointment of Marshal Philippe 
Pétain, as head of government. Pétain sued for peace and signed an Armistice on June 22, 1940. Following the Armistice, nearly half of the two million French prisoners of war, were released. The remaining POWs provided forced labor for their captors (Herbert, 1997). Under the terms of the agreement, France ceded territory to the Reich, occupied Belgium and Italy. The remainder was divided into the Occupied Zone, under direct German control, and the Free Zone. Pétain moved the government to Vichy in the Free Zone where the constitution was suspended and plenary powers were granted to the Marshal's government. When Allied successes in North Africa revealed the military weakness of the Vichy regime, the Germans marched into the Free Zone in November 1942. However, from almost the beginning, the government in Vichy retained control of economic policy, which was generally uniform across both zones, with laws subject to approval of German authorities when they were implemented in the Occupied Zone.

The extraction of resources from France was driven by the changing needs of the Nazi war machine. When the German Army first rolled into France, they were supplied with an occupation currency that could not be spent in Germany or exchanged against the Reichsmark. The Bank of France was required to accept these notes and redeem then in francs, charging them as costs of occupation to the French government ${ }^{6}$. The exchange rate between the franc and the occupation currency was proclaimed to be 20 to one, which later became the official rate between the Reichsmark and the franc. According to Milward (1970, p. 55), this rate overvalued the mark by 50 percent using the dollar-franc and dollar-Reichsmark rates of June 1940 or 54 to 63 percent using the exchange rates against the pound in 1939. Exchange rates for September 1, 1939 implied an even greater overvaluation (Andrieu, 1990, p. 148). French goods were therefore intended to be cheap for the occupying German army.

International trade between the Reich and the vanquished Republic was restructured with a bilateral clearing agreement based on the arrangements that Germany had engineered with Central and Southeastern European countries in the 1930s (Neal, 1979). Foreign exchange was strictly controlled and allocated for government-approved imports. The Bank of France bought marks from exporters at the fixed rate of exchange, producing an expansionary monetary policy fueled by a net surplus that stood at 111.4 billion francs by the war's end (Bettelheim, 1946). Yet, the transfer of resources under

\footnotetext{
${ }^{6}$ This currency was gradually demonetized between April 30, 1941 and December 1, 1943 (Andrieu, 1990, p. 151).
} 
the bilateral clearing agreement was modest compared to the direct occupation costs. The charges were set far above the actual cost of occupation, providing the German authorities with considerable means to purchase war goods and other products in France. In the Armistice talks in late 1940, the French were stunned and protested when they were informed during the negotiations that they would be obliged to pay occupation costs of 20 million Reichsmarks or 400 million francs a day. Added to these were indemnities paid to owners of property occupied by the German army and compensation for requisitions (Patat and Lutfalla, 1990, p. 98).

According to the French negotiators contesting the occupation costs in 1940, the head of the German economic delegation Hans Hemmen "indicated that the French money payments would be spent in France: but with that money the Germans will be able to buy the whole of France." He justified the reparations by reminding the French of those imposed on Germany in the treaty of Versailles. He acknowledged that:

The payment demanded is very heavy, and Germany knows by experience how ruinous such charges are. That is why the German government has seen this question from an economic point of view, since at the same time that it has demanded these payments from France, it has proposed to her an economic system which frees France from the anxiety of ruin. (quoted in Milward, 1970, p. 61).

At the outbreak of the war, French real GDP per capita exceed the level in Germany, and the Germans saw no reason why this difference should be sustained. The willingness of Vichy to collaborate with the Nazis reflected the rough consensus of the majority of the French political class that cooperation was in the long-term national interest. Faced with Nazi ruthlessness and the threat to society on many levels, the French concluded that collaboration was a lesser evil, permitting a peaceful rather than a violent seizure of resources, with the costs of extraction kept quite low for the exploiter. ${ }^{7}$ Occupation costs would be paid by the creation of money in Germany's account in the Bank of France. If Vichy wished to contain the inflationary potential of this policy, the government could issue bonds to the French public and sterilize the creation of francs.

Funds from the occupation charges initially proved greater than the Germans could spend and accumulated as unspent credits (Banque de France, $\underline{\text { Comptes rendus, }}$

\footnotetext{
${ }^{7}$ Liberman (1996) found that France contributed approximately half of the income extracted from Occupied Western Europe, although rates of exploitation were higher in the Netherlands, Belgium and Norway.
} 
1941-1942), a consequence of Blitzkrieg's success. The rising unused credits and French protests, combined with an offer to exchange French shares in Polish and Balkan firms desired by the Reich, produced a new agreement on occupation costs. In May 1941, they were lowered to 15 million Reichsmarks or 300 million francs per day. However, the failure of Blitzkrieg to deliver the Soviet Union to the Reich prompted a complete mobilization of Germany and its satellites for war. Occupation costs were raised to 25 million Reichsmarks or 500 million francs a day on December 15, 1942. Occupation charges including bilateral trade credits, presented in Table 4, quickly overshadowed ordinary government expenditures. Taxes were increased to pay for some of the costs. In spite of the shrinking economy and inflation, real tax revenue was nearly constant between 1938 and 1944, ranging from 55 to 59 billion 1938 francs. Tax rates on capital and on personal incomes were all increased, the base was broadened, and the collections were improved (Magairaz, 1991, p. 544).

\section{Table 4}

\section{How France Financed Germany's Exploitation} (billions of francs)

\begin{tabular}{|c|c|c|c|c|c|c|}
\hline & $\begin{array}{c}\text { Conventional } \\
\text { Government } \\
\text { Expenditure }\end{array}$ & $\begin{array}{c}\text { Occupation } \\
\text { Costs }\end{array}$ & $\begin{array}{c}\text { Total } \\
\text { Government } \\
\text { Expenditure }\end{array}$ & $\begin{array}{c}\text { Taxes } \\
\%\end{array}$ & $\begin{array}{c}\text { Debt } \\
\%\end{array}$ & $\begin{array}{c}\text { Money } \\
\%\end{array}$ \\
\hline 1939 & 150.1 & & 150.1 & 42.2 & 28.4 & 29.5 \\
\hline 1940 & 203.6 & 81.6 & 285.2 & 25.2 & 27.2 & 43.6 \\
\hline 1941 & 120.8 & 144.3 & 265.1 & 30.3 & 34.6 & 34.4 \\
\hline 1942 & 133.2 & 156.7 & 289.9 & 35.6 & 26.1 & 40.4 \\
\hline 1943 & 135.3 & 273.6 & 408.9 & 29.8 & 34.7 & 37.6 \\
\hline 1944 & 212.8 & 206.3 & 419.1 & 29.5 & 52.6 & 14.9 \\
\hline
\end{tabular}

Sources: INSEE (1966), Patat and Lutfalla (1990) and Milward (1970).

Inflation during and after World War I produced an unexpected default on government debt. Fearful that a new inflation would frighten investors and drive up yields that would raise government financing costs, Vichy's policy makers sought to prevent the growing stock of currency from having its full inflationary effect. The government attempted to "close the circuit" (the so-called "politique de circuit.") by selling bonds to repay its liabilities to the Bank of France. The Bank and Treasury officials watched for any leaks from the circuit, deploying the tools of financial repression to plug them.

Both Vichy finance ministers, Yves Bouthillier and Pierre Cathala, concurred and that inflationary finance was unacceptable; and the later termed the defense of the franc a 
"national duty" (Cathala, 1948, p. 65) Bouthillier, like other officials, believed that an accommodating French government would be less onerous than direct German administration. Ultimately, by controlling inflation he hoped to preserve a healthy, stable economy by the end of the war so that France would have a place in the new economic order of Europe. The governor of the Banque de France, Yves Bréart de Boisanger and a member of the French delegation to the armistice commission, conceded that "I constantly forced myself not to view the occupation charges from a purely financial point of view. If I had done so, I would have soon demanded that the government suspend payments. I did not do so because I was convinced of the need to reconcile the two countries and I believed that it would be necessary not just to think in terms of solely France's interest but it would be tightly tied to the question of the economic organization of Europe." (Magairaz, 2002, p. 51).

Concerned about its financing costs, Vichy wanted to keep interest rates low. Beginning in 1939, the Bank of France's discount and 30-day advance rates were set at 2 percent and the rate on advances against securities at 3 percent. The only revision was in 1941, when the rates were set at 1.75 and 3 percent. Open market operations were employed to keep the rate on the long-term bonds, the rentes, at approximately 3 percent. However, in this inflationary environment, financial repression was needed to maintain low yields. Banks and savings banks were pressured to buy bonds, shifting their portfolios away from commercial and mortgage credit to government bonds (Margairaz, 1991). From one-third of their portfolios in 1938, short-term bonds rose to 90 percent in 1943.

Wage and price controls were imposed from the very beginning in 1939. Wages soon began to lag prices and Mitzakis (1945) estimated that, by 1944, wages had risen on average by 60 percent and prices, excluding the black market, had increased by 150 percent. Price controls led to shortages and the French government instituted a system of rationing in 1940. A black market quickly emerged; coupled with tax evasion, the demand for currency increased. Rationed consumer goods and the lack of alternative investment opportunities encouraged the public to deposit funds in low interest bank and savings accounts.

In general, this collection of policies was successful in keeping the nominal yields for government bonds low. Real rates were considerably lower. Even at the official 
rates, which certainly are under-estimates, inflation ranged between 17 and 24 percent for 1940-1944, implying negative real rates of interest. The drive to sell bonds and channel savings into government securities reduced new capital formation and the ability to supply the German war machine. The low interest policy did produce a boom in the stock market, which was then subjected to capital controls (Oosterlinck, 2003). However, the government could not completely suppress the equities market as new investment was required to re-equip French industry so that it could provide for the Nazi war machine. Consequently, Vichy moved more towards a command economy where resources were allocated to specific industries.

Table 5

French POWs and Civilian Workers in Germany, 1939-1944

\begin{tabular}{|l|r|r|r|r|r|}
\hline & May 1939 & September 1941 & November 1942 & Fall 1943 & August 1944 \\
\hline $\begin{array}{l}\text { French Civilian } \\
\text { Workers in Germany }\end{array}$ & 6,669 & 48,567 & 134,518 & 649,000 & 654,782 \\
\hline POWs & None & 952,000 & 931,000 & 739,000 & 599,967 \\
\hline TOTAL & 6,669 & $1,000,567$ & $1,065,518$ & $1,388,000$ & $1,254,749$ \\
\hline
\end{tabular}

Source: Herbert (1997), except for 1943, Liberman (2001).

The final important feature of occupation was the transfer of labor from France to Germany. Data on the transfer of French labor to Germany is presented in Table 5. In addition to the POWs who remained in Germany, Hilter's demanded the conscription of French workers to work in Germany in May 1942. After initially attempting to exchange three French workers for each prisoner of war, Vichy bowed to conscription. Compulsory labor service was established on February 16, 1943; all men born between January 1, 1920 and December 31, 1922 were liable for two years service. This coercive approach soon led many Frenchmen to join the resistance. In September 1941, there had been 1,000,567 POWs and 48,567 civilian workers in Germany; by the fall of 1943, POWs had fallen to 739,000 while civilians rose to 649,000 . These $1,388,000$ workers in German represented a reduction of about 10 percent of the French labor force.

\section{A Model of Occupation Finance}

The rapid decline in French GDP, even with a substantial unmeasured black market, suggests that a huge burden was imposed on the economy. To assess the Vichy's policies and alternate strategies, we begin with Ohanian's (1997) and McGrattan and 
Ohanian's (2003) basic model of a wartime economy. We expand our version of this neoclassical growth model to include financial assets and allow for wartime controls.

In our model, there are a large number of identical, infinitely-lived households, competitive firms owned by households, and a government. There is no uncertainty, and all agents have perfect foresight. There is a single non-durable good, which is produced with capital and labor and is used for consumption and investment. The two financial assets are money and one-period government bonds.

Households own capital and make all investment decisions. Capital depreciates at the rate $\delta, 0<\delta<1$. Households are endowed with one unit of time per period, which can be spent for leisure $\mathrm{l}_{\mathrm{t}}$ or labor $\mathrm{n}_{\mathrm{t}}$. However, to account for the POWs and the labor drafted to work in Germany, we assume that the labor available is lowered exogenously by $d_{t}$ hours, so the time constraint is $n_{t}+l_{t}=1-d_{t}$.

The household lifetime utility function is ${ }^{8}$ :

$$
\mathrm{V}=\sum_{t=0}^{\infty} \beta^{\mathrm{t}} \mathrm{u}\left(\mathrm{c}_{\mathrm{t},}, \mathrm{M}_{\mathrm{t}+1} / \mathrm{P}_{\mathrm{t}}, \mathrm{l}_{\mathrm{t}}\right)
$$

which depends on consumption $c_{t}$, real cash balances $\mathrm{M}_{\mathrm{t}+1} / \mathrm{P}_{\mathrm{t}}$, and leisure $\mathrm{l}_{\mathrm{t}}$. For the period utility function $\mathrm{u}$, we adopt the functional form:

$$
\mathrm{u}=\mathrm{a} \ln \left(\mathrm{c}_{\mathrm{t}}\right)+(1-\mathrm{a}) \ln \left(\mathrm{m}_{\mathrm{t}}\right)+\Psi 1_{\mathrm{t}}^{1-\eta} /(1-\eta) \quad 0<\mathrm{a}<1, \Psi>0, \eta>0, \eta \neq 1
$$

where the last term becomes $\Psi \ln \left(1_{t}\right)$ in the case that the labor supply elasticty $\eta$ takes the benchmark value of one. This functional form implies that consumption and labor decisions are independent of the households' portfolio decisions, and money is superneutral (Walsh, 2003).

Households start period $t$ with $k_{t}$ units of capital, $B_{t}$ units of government bonds and $\mathrm{M}_{\mathrm{t}}$ units of money and rent out labor and capital at the wage and rental rates $\mathrm{W}_{\mathrm{t}}$, and $Q_{t}$, and receive profits $Z_{t}$ and the bonds revenue $\left(1+r_{t}\right) B_{t}$. They use this income to pay taxes, purchase goods for consumption, investment and net exports at the price $\mathrm{P}_{\mathrm{t}}$, invest in new government bonds, and modify their cash balances. Their budget constraint is then:

$$
\begin{aligned}
\left(1-\tau_{\mathrm{nt}}\right) \mathrm{W}_{\mathrm{t}} \mathrm{n}_{\mathrm{t}}+\left(1-\tau_{\mathrm{kt}}\right) \mathrm{Q}_{\mathrm{t}} \mathrm{k}_{\mathrm{t}}+\mathrm{Z}_{\mathrm{t}}+\left[1+\mathrm{r}_{\mathrm{t}}\left(1-\tau_{\mathrm{bt}}\right)\right] \mathrm{B}_{\mathrm{t}}= \\
\mathrm{P}_{\mathrm{t}} \mathrm{c}_{\mathrm{t}}+\mathrm{P}_{\mathrm{t}}\left[\mathrm{k}_{\mathrm{t}+1}-(1-\delta) \mathrm{k}_{\mathrm{t}}\right]+\mathrm{P}_{\mathrm{t}} \mathrm{nx}_{\mathrm{t}}+\mathrm{T}_{\mathrm{t}}+\mathrm{B}_{\mathrm{t}+1}+\mathrm{M}_{\mathrm{t}+1}-\mathrm{M}_{\mathrm{t}}
\end{aligned}
$$

\footnotetext{
${ }^{8}$ The money-in-the-utility-function assumption allows for a interest rate elastic money demand and is equivalent to other formulations; see Feenstra (1986).
} 
where $\tau_{\mathrm{nt}}, \tau_{\mathrm{kt}}$ and $\tau_{\mathrm{bt}}$ are respectively the tax rates on income from labor, capital and bonds, and $\mathrm{T}_{\mathrm{t}}$ are lump-sum taxes. Equation 3 states that income is composed of after-tax labor income $\left(1-\tau_{\mathrm{nt}}\right) \mathrm{W}_{\mathrm{t}} \mathrm{n}_{\mathrm{t}}$, after tax capital income $\left(1-\tau_{\mathrm{kt}}\right) \mathrm{Q}_{\mathrm{t}} \mathrm{k}_{\mathrm{t}}$, profits $\mathrm{Z}_{\mathrm{t}}$ (in the flexible price competitive equilibrium $Z_{t}=0$ ), and the bond revenue (principal and after-tax interest). This income is used for consumption $\mathrm{P}_{\mathrm{t}} \mathrm{c}_{\mathrm{t}}$, investment gross of depreciation $\mathrm{P}_{\mathrm{t}}$ $\left[\mathrm{k}_{\mathrm{t}+1}-(1-\delta) \mathrm{k}_{\mathrm{t}}\right]$, net exports $\mathrm{P}_{\mathrm{t}} \mathrm{nx}_{\mathrm{t}}$, lump-sum taxes $\mathrm{T}_{\mathrm{t}}$, investment in new bonds $\mathrm{B}_{\mathrm{t}+1}$, and increases in cash balances $\mathrm{M}_{\mathrm{t}+1}-\mathrm{M}_{\mathrm{t}}$.

The households' optimization problem is to maximize their lifetime utility subject to the previous time and budget constraints, and transversality conditions requiring that the present discounted values of future bonds and money converge to zero in the limit. Firms rent labor and capital, and produce consumption and investment goods with the Cobb-Douglas production function:

$$
\mathrm{y}_{\mathrm{t}}=\mathrm{k}_{\mathrm{t}}^{\theta}\left(\mathrm{A}_{\mathrm{t}} \mathrm{n}_{\mathrm{t}}\right)^{1-\theta}
$$

where the labor-augmenting technology $\mathrm{A}_{t}$ grows at the constant rate gamma. Firms act competitively to maximize profits $\mathrm{Z}_{\mathrm{t}}=\mathrm{P}_{\mathrm{t}} \mathrm{y}_{\mathrm{t}}-\mathrm{W}_{\mathrm{t}} \mathrm{n}_{\mathrm{t}}-\mathrm{Q}_{\mathrm{t}} \mathrm{k}_{\mathrm{t}}$.

The government sets public consumption $\mathrm{g}_{t}$, taxes, bonds and money satisfying the period budget constraints:

$$
\mathrm{P}_{\mathrm{t}} \mathrm{g}_{\mathrm{t}}+\left(1+\mathrm{r}_{\mathrm{t}}\right) \mathrm{B}_{\mathrm{t}}=\tau_{\mathrm{nt}} \mathrm{W}_{\mathrm{t}} \mathrm{n}_{\mathrm{t}}+\tau_{\mathrm{kt}} \mathrm{Q}_{\mathrm{t}} \mathrm{k}_{\mathrm{t}}+\tau_{\mathrm{bt}} \mathrm{r}_{\mathrm{t}} \mathrm{B}_{\mathrm{t}}+\mathrm{T}_{\mathrm{t}}+\mathrm{B}_{\mathrm{t}+1}+\mathrm{M}_{\mathrm{t}+1}-\mathrm{M}_{\mathrm{t}}
$$

which state that expenditures for goods and payments for bonds (principal and interest) must be financed with taxes on labor, capital and bonds, lump-sum taxes, issues of new bonds and seigniorage. A consequence of the transversality conditions is that, in equilibrium, the present discounted value of all government expenditures is equal to the present discounted value of all government revenues.

The equilibrium condition for the goods market is:

$$
\mathrm{y}_{\mathrm{t}}=\mathrm{c}_{\mathrm{t}}+\left[\mathrm{k}_{\mathrm{t}+1}-(1-\delta) \mathrm{k}_{\mathrm{t}}\right]+\mathrm{nx}_{\mathrm{t}}+\mathrm{g}_{\mathrm{t}} .
$$

which states that the aggregate goods supply is equal to the aggregate goods demand for private consumption, investment, net exports and government expenditure.

The values for the labor drafted to Germany, tax rates, lump-sum taxes, government expenditure and net exports are treated as exogenously determined, as are the initial values for capital, bonds and money. A competitive equilibrium is, then, a set of sequences of quantities and prices such that: given prices, households and firms solve their optimization problems; the government's period budget constraints are satisfied; and 
the labor, capital, goods and bonds markets clear. It is easy to show that the government's period budget constraints follow from the other equilibrium conditions (Walras' Law).

To model the wage controls imposed during the war, we also introduce the following alternative equilibrium, where $\lambda$ represents the share of the economy subject to wage and price controls. In each war year, the real wage is equal to a weighted average of the exogenously controlled wage and the wage that would clear the labor market in that year if there were no real wage controls, with the weights respectively equal to $\lambda$ and $1-\lambda$. While labor supply is determined by the households, labor demand is set by firms subject to an additional rationing constraint in wartime, requiring their labor demand not to be larger than average (per firm) labor supply. By the manipulation of wage and price controls, the wartime government exogenously affects the real wage, leaving households to make their labor supply decision.

One key feature of wartime finance we do not attempt to directly model is the financial repression that permitted the Banque de France to maintain pegged nominal interest rates on government securities, which yielded highly negative real yields. In our model, a huge wedge would have to exist between government bonds and other financial instruments, otherwise they would not be held. Essentially by compelling financial institutions to fill their portfolios with bonds and placing restrictions on the stock market, Vichy was able to fix the price of government securities and to some extent the quantities. $^{9}$

After normalizing all nominal variables by the price level, we solve the system of nonlinear equations describing the equilibrium using the shooting algorithm described in Ljunqvist and Sargent (2004). To begin the calibration, we require information not only on the initial state of the economy at the outset of the war and the wartime path of the variables, but also on the steady state variables.

\section{The Structure and Parameters of the Economy}

The selection of the parameters for the latter is not a trivial exercise, as it should reflect what policy makers thought would be the long-term path of the economy when they made wartime financial decisions. First, there is the question of the underlying growth rate of the economy. Growth in the interwar years was highly uneven; however

\footnotetext{
${ }^{9}$ Makinen and Woodward (1990) describe the results of pursuing a similar policy after World War I.
} 
from the late nineteenth century to 1929 and during the postwar World War II period it was approximately 2 percent, the value we adopt here for the steady state growth rate. ${ }^{10}$ This is the long-term rate that policy makers would have optimistically hoped to see in the postwar period. The length of a period in the model is one year, and we set the preference discount factor $\beta$ equal to .98 , which implies a 2 percent preference discount rate and, given the 2 percent growth rate of the economy, a 4 percent steady state real interest rate.

The outbreak of the war and its attendant shocks drove the economy far from its steady state values. The wartime values for our exercise, from 1939 military build up to 1944, were obtained from a variety of sources. We used Carré, Dubois and Malinvaud's (1975) estimates of GDP as they are the only source to provide wartime figures. There is no data on aggregate wartime consumption and investment, although qualitative evidence points to vary large declines in these components. ${ }^{11}$

Only postwar data is available to set the parameter values for the production function. Using the years 1938 and 1949-1958 provided by INSEE (1966), the factor shares are fairly stable and these are taken to represent their steady state values. For 1938, labor earned 67.7 percent of national income and for 1949-1958 it ranged between 66 and 68 percent; hence 67 percent is selected. Consequently, the parameter $\theta$, capital's share of total output, is set at 0.33 . The depreciation rate, $\delta$, is 10 percent, a number that makes the observed postwar capital-output ratio consistent with the steady state capitaloutput ratio implied by the model. This depreciation rate is very close to the 10.6 percent found by INSEE (1966). There were large changes in factor shares during World War II, as documented by Piketty (2001). His factor shares closely match INSEE's estimates, with labor's portion climbing from 70 percent in 1940 to 87 percent in 1943 before drifting back to approximately 68 percent.

\footnotetext{
${ }^{10}$ The standard authority Carre, Dubois and Malinvaud (1975, p. 21) give the growth rates of GDP for 1896-1913 as $1.9 \%$, for 1913-1929 as 1.7\%, 1929-1938 -0.4 percent and 1938-1949 as 0.9. Over 18961929 , it was $1.8 \%$, and for 1929-1963, 2.2\%. More recently Dormais (2004) finds the growth rate of GDP for $1900-1913$ as $1.63 \%$ and for $1973-1998$ as $2.1 \%$.

${ }^{11}$ INSEE (1966, p. 553) estimated that GNP was 446 billion current francs in 1938, with consumption accounting for 74.2 percent, government consumption 12.7 percent, gross fixed capital formation 13.2 percent, and exports and imports at 10.8 and 11.0 percent of GDP. More recently, in a reexamination of the data for 1935-1938, Toutain (1997. p.15, 58 85) apportions 74.3 percent of national income to consumption, 12.9 percent to government consumption, 15.6 percent to gross domestic capital formation, and 1.3 percent to government capital formation, with exports and imports accounting for 7.0 and 11.1 percent respectively.
} 
For the steady state, we assume small government fin-de-siècle values for the ratio of government expenditure to GDP and tax rates. Before the First World War (1911-1913), the share of government was about 10 percent (INSEE, 1966). After the postwar stabilization, in the good years of 1927-1931, it was 14 percent, although this higher level still contained some World War I costs, notably veterans' benefits and interest payments. The share of government jumped after World War II, reflecting the appearance of the modern welfare state. Choosing a higher value from this period for the steady state seemed inappropriate as it is unlikely that Vichy officials would have anticipated or sought this increase. Their goal was closer to a restoration of the preWorld War I period, and thus we set the value for government expenditure to national income at 10 percent, which is also close to what would have been attained once the effects of the First World War had disappeared. ${ }^{12}$ We assume that government expenditures were exogenously determined during the Second World War, consisting of the very limited conventional expenditures of Vichy plus the required transfers to the Nazis. The Germans used the funds in their account at the Bank of France to purchase goods in France as their war effort required. They were not interested in some nominal level of transfer but in obtaining real resources. To set what they extracted in the model, we fix the ratio of actual government expenditures to the steady state GDP. The use of official wartime output would be somewhat misleading as this omits the black market, which should have figured in the Nazis calculations, as they probably thought of what they could obtain in terms of the some steady state GDP.

Although it would be preferable to have marginal tax rates, average tax rates are employed here in the absence of a thorough study of the tax structure and its incidence. Tax rates on labor and capital are imputed by taking the total tax revenues levied on each factor divided by their share of national income. Based on data from Piketty (2001) and INSEE (1966), we estimate that in 1913 the tax rates were 11 percent for labor and 10 percent for capital, yielding a small budget surplus. For the period from 1930-1938, the tax rates for labor and capital were estimated to be 14 and 11 percent. We selected the pre-World War I tax rates because, as in the case of government spending, it probably represented the government's long-term objective. As will be seen in our calibrations, the estimated sustainable debt in the steady state for these values is close the observed

\footnotetext{
${ }^{12}$ We ignore local government expenditure, which are harder to track, and are effectively assumed to be local lump-sum taxes with local transfers.
} 
debt at the outset of the war. To obtain the wartime tax rates, Piketty's (2001a) decomposition of the state's revenue into taxes levied on capital, labor and mixed sources and INSEE's data are employed, splitting the mixed revenues between capital and labor. The combined effects of the rise in wartime tax rates and the fall in capital's share of income led the tax rate on capital to rise from 11.8 percent in 1938 to a peak of 59.8 percent in 1943, while the tax rate on labor increased to 16.0 percent.

INSEE (1966) gives the total nominal debt of the central government. In 1939, it stood at 423 billion francs, climbing to 1334 billion by the end of the war. The debt to GDP ratio thus rose from 0.98 to 2.16 . The steady state for the French economy was considerably lower. Bordo and Hautcoeur (2003) find the debt to GDP ratio to be about .80 in 1910 and falling to nearly .70 at the beginning of World War I. After the postwar stabilization this ratio returned to .80 in 1930 .

We view the steady state exchange rate regime to be the gold standard, although it is not explicitly modeled. Until the break up of the Bretton Woods System, the French ideal exchange rate regime was the gold standard; and the Vichy government, like its interwar predecessors and postwar successors sought its return (Bordo, Simard, and White, 1995). We approximate a steady-state gold standard equilibrium by setting net exports equal and inflation equal to zero. We treat imports and exports as exogenous given the highly regulated Nazi trade regime.

In the steady state, the ratio of money (M2) to GDP is set at 40 percent, as this was approximately the ratio in the "good years" of 1927-1931 and in the late 1940s and early 1950s. In addition, we place the steady state growth rate of the money supply at 2 percent to mirror the growth of the economy. For the war years, we employ INSEE's (1966) retail price index as a measure of inflation. The estimates of M2 during the occupation are provided by Patat and Lutfalla (1990).

There are no estimates of the capital stock for the late 1930s. Carré, Dubois and Malinvaud (1975, p. 120) estimate the total capital-output ratio in 1949 to be 3.06 and for productive capital 1.93, which then slowly declined in the 1950s, reaching 1.61 by $1959 .{ }^{13}$ For our purposes we use a rough estimate of 2 to provide an estimate of productive capital. However, we do know that the occupation took its toll on capital, just as it did on labor. Carré, Dubois and Malinvaud (1975, p. 534) set the value of gross

\footnotetext{
${ }^{13}$ In 1913 , they estimate the capital-output ratio to be 2.81 and the productive capital-output ratio to be
} 1.61 . 
productive capital on average at 56 billion francs in 1956 prices in 1921-1930, 59 billion for 1931-1940 and only 15 billion for 1941-1945. ${ }^{14}$

Measurement of the labor force is crucial given its decline during the War. In 1938, Carré, Dubois and Malinvaud (1975, p. 59) put the total population of France at 42.0 million with a labor force of 19.5 million of which 16.4 million were employed in productive sectors, which excluded the unemployed, draftees, and government officials. During the war, the labor force shrank, but by 1946, it had recovered to 16.8 million, although it subsequently declined to 16.4 million by 1957 . Thus the last figure is used as the steady state level. The leisure preference parameters are set equal to values that imply that the representative household spent one-third of its time working in steady state.

During the war, the labor force collapsed from its prewar level of 16.4 million. The war gradually reduced the labor force. First, there was the loss of Alsace-Lorraine, which had population of 1.9 million (Milward, p. 39). Assuming the same rate of labor force participation as the rest of France in 1938, the loss of Alsace-Lorraine would have reduced the labor force by 0.75 million. $^{15}$ Defeat also brought 300,000 deaths (Bettelheim, 1946) and the initial internment of 1.2 million French prisoners-of-war. The POWs who were called up to duty are assumed to have been previously productive and should thus be subtracted from the labor force in 1940, leaving a total of 14.1 million workers. According to Carré, Dubois and Malinvaud (1975) the population continued to shrink by perhaps 100,000 per year, and the work force is thus reduced for 1941 and 1942. As seen in Table 5, the last great shock was the relève, which occurred in 19431944 and quickly reduced the labor force until Liberation.

A critical parameter is the elasticity of labor supply. In most business cycle models of the U.S. economy, including Ohanian's model (1997) of the U.S. World War II economy, labor elasticity needs to be assumed to be very high in order to mimic the observed behavior of labor and output. ${ }^{16}$ Thus, we set the labor elasticity to be one.

\footnotetext{
14 In addition, Carré, Dubois and Malinvaud report (p. 151) an estimate of 137.7 billion current francs for fixed reproducible capital in 1913. Taken with Toutain's estimate of GDP of 49.6 billion francs for 1913, there is an implied capital output ratio of 2.78 .

${ }^{15}$ Some of this population also fled or was driven into France as Hitler moved to "Germanize" the region, but there are no estimates but it is compensated for by the loss of labor in other small annexed regions.

${ }^{16}$ Microeconomic studies estimate low labor supply elasticities and many models implement a HansenRogerson model where labor is indivisible so workers chose only between full employment or
} 
However if we assume labor supply to be very elastic and the labor market to be free and competitive, there is a boom in Occupied Vichy, contrary to events. But wages were not freely set as wage and price controls plus rationing were imposed at the outset of the war. Vichy created controls, but as is often the case with wage and price controls, the drift in prices, including uncontrolled goods and the black market, reduced the real wages. Thus, as already described the government raised wages to adjust for the lost of purchasing power. Very broadly this policy might be described as setting a fixed real wage. To estimate the real wage, we use the weighted index of male workers and professionals nominal salaries (INSEE, 1966, p. 424). Indexed by retail prices, these real wages fell from 100 in 1939 to 60 in 1944 . Other measures of wages or earnings show very similar declines. This fixed real wage is set by this series during the war, while wages are competitively determined afterwards. In wartime, workers were paid less than their marginal product. The difference is not assigned to capital but is given back to labor as a lump sum rebate. Although this minimizes the distortion, it produces a drop in the labor supply that approximates the observed decline. In addition, recognizing the fact that many workers evaded the controls and obtained a higher real wage because they worked in the agricultural sector or in the black market, we allow only 75 percent of the reduction in the real wage so that we focus on the wartime equilibrium associated with $\lambda=0.75$. The unwillingness of the French to work, driven partly by patriotic motives and partly by below market wage rates, should be captured by this part of the model.

\section{Modelling Postwar Stabilization Policy}

Up to this point, we have only considered wartime policies and not how any postwar debt and monetary overhangs would be handled. However, our results require an explicit stabilization policy, otherwise an immediate return to steady state taxation, expenditure and inflation policies leaves the debt well above its steady state value and it would grow explosively. The surplus generated in steady state is insufficient to cover war-generated interest payments, even with the lower levels of non-interest expenditures. Thus, in 1944 the government cannot revert steady state policies because they do not produce an equilibrium. Some postwar stabilization package is required. Most studies of war finance focus only on wartime finance and a separate literature focuses on postwar

unemployment, providing a high elasticity from the extensive margin of workers moving in and out of the work force (Rebelo, 2005). 
stabilization policies. Here, we provide a more integrated approach that combines wartime and postwar financing, which would have been included in government plans.

Many types of stabilization packages with different distributional effects were possible after the war. Except for pronouncements about safeguarding the franc, Vichy's postwar plans were opaque; though its choices and those of any liberated government certainly differed. Rather than assume that the public knew in 1939 what stabilization package would be adopted in addition to knowing all the wartime policies, we take an initial agnostic view and instead calculate what would be the required size of a nondistortionary stabilization package to move the economy back to its steady state path. ${ }^{17}$ In our exercise above, we calculated the size of the required program by asking what is the lump-sum tax needed to reduce the postwar debt to its steady state level. We picked a five year period for the program, and apportioned the lump-sum tax over these years to bring the end-of-war debt down to the sustainable debt to GDP level.

In addition to the debt overhang, a monetary adjustment is also required. Our steady state money to income ratio is 0.40 , which is the rate observed in the data in the immediate prewar period. During the war the real money balances rise as a consequence of the steady monetary expansion. To bring real money down to the steady state level we impose a deflationary program, consisting of a five year monetary reduction that lowers the real money level to its steady state. This program is similar to the deflationary programs instituted by the British after 1815 and after World War I to put the pound back on the gold standard at its prewar parity; and which the French considered but did not attempt after World War I (Bordo and Hautcoeur, 2003).

\section{The Cost of Occupation}

Given that money is supernuetral, we can first examine the real side of the economy in Figure 1. The choices for the real sector are separable from the portfolio decision of households and the financing decision of the government. We set the production function parameter A so that steady state output is one. Thus, in the figures, output, consumption, investment, capital, and debt are presented relative to this benchmark. Labor is set so that the initial supply is equal to one third of a day. The

\footnotetext{
${ }^{17}$ The length the stabilization period is arbitrary but approximates the post-World War I periods for Britain and France, which stabilized in 1925 and 1926.
} 
dotted lines represent the steady state growth path for each variable and the starred lines the path of the observed variable, where it was available.

Figure 1
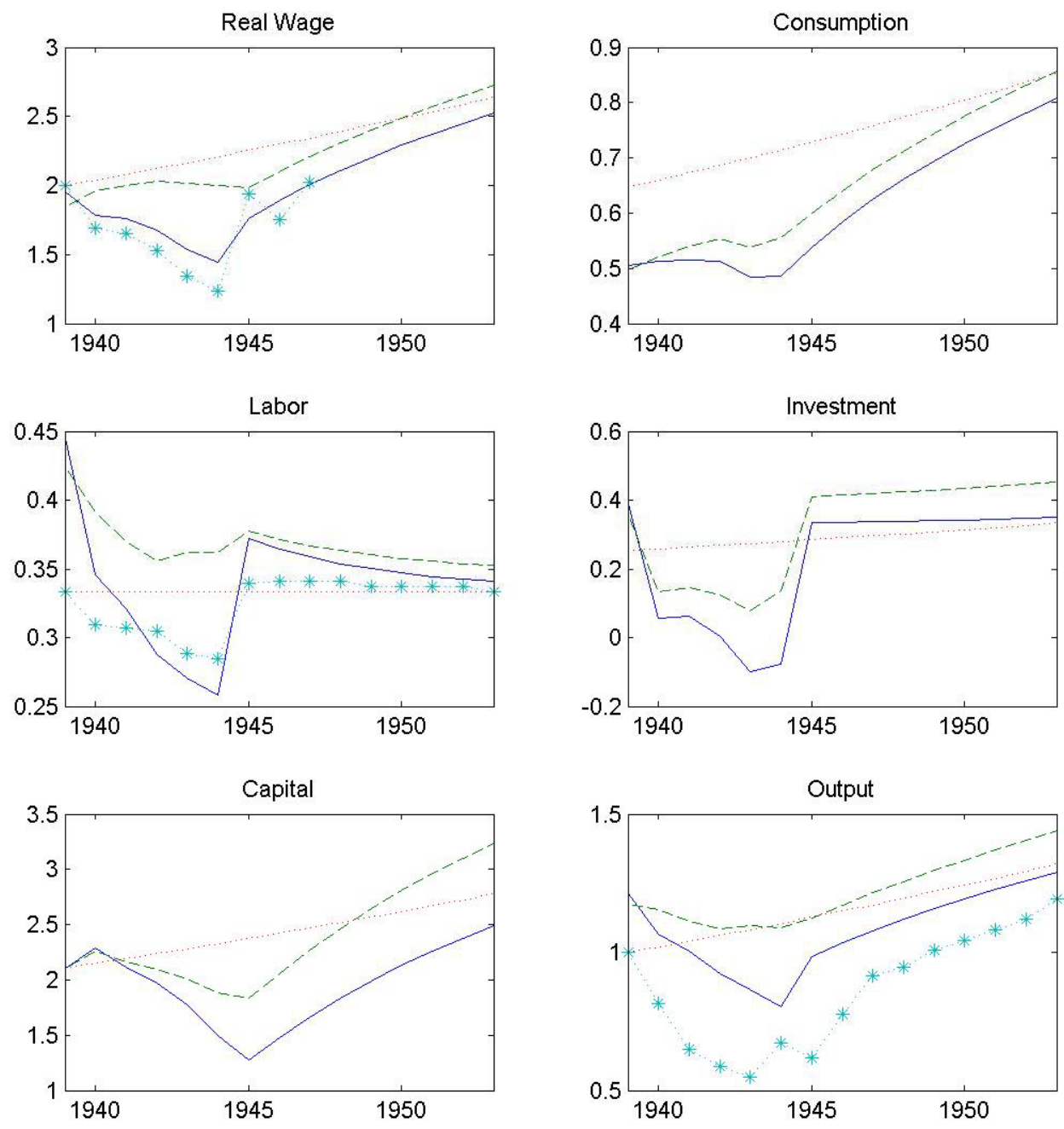

The behavior of the real sector with a competitive labor market, represented by the dashed line and with a labor market subject to wage and price controls, indicated by the solid line in Figure 1. ${ }^{18}$ Because of the high labor elasticity in a free labor market, the labor supply does not sharply decline like the actual data. Its downward movement is only driven only by higher labor taxes and the relève. Consequently, output remains relatively level. But, when real wages are controlled, labor supply drops, more closely

\footnotetext{
${ }^{18}$ As a check for our measure of controlled prices and wages, we computed an index of real labor earnings
} divided by the labor supply, which closely parallels our direct measure of real wages during the war years. 
following the actual data. This reduction in labor produces sharper falls in output, consumption, investment and capital. While this collapse is less than the decline officially recorded by the starred lines, the actual data does not include black market activity, which would lower the burden. ${ }^{19}$ Unfortunately, there are only rough estimates of its size. Sédillot (1985) believed that the volume of illegal transactions were 10 to 30 percent of the legal market, with a peak in $1943 .{ }^{20}$ Reviewing the available evidence, Sanders (2001) concluded that the black market averaged 20 percent of GDP. Its inclusion in official data would substantially reduce gap between these numbers and our model. We do not have series for private capital, investment and consumption, but the fragmentary data suggests that both seriously shrank over the course of the occupation. The model appears to capture the burden of occupation payments, increased in 1943, as consumption dips again. These huge losses seem realistic given what we know happened to food rations. According to Milward (1970), the rations for bread, meat and fat in 1943-1944 were 70, 18 and 31 percent of the prewar levels. These were basic necessities and consumption of other perishables and durables collapsed. Although the black market helped to supplement these low levels, it did not make up the difference for the whole population.

A key feature of the model is the calculation of the debt level sustainable by the steady state parameters of the model. In the steady state there is a small surplus dictated by the fact that government expenditure is 10 percent of GDP and the tax rate on all factors is 11 percent. Given these and other parameters, we can compute the steady state path of money and the steady state debt such that the present value of future surpluses plus seigniorage produces a debt to income level that is stationary. If actual debt is more that this ratio, debt will grow explosively; and if it is less, it will implode. The sustainable steady state debt ratio is 0.864 . This value is very close to the pre-World War I (1910-1913) ratio of just under 80 percent and the ratio attained after the post-World War I stabilization (1929-1930) of 80 percent (Bordo and Hautcoeur, 2003). Compared to our sustainable ratio, the actual ratio is slightly higher for 1939, which reflects the

\footnotetext{
${ }^{19}$ According to Aly (2000) and Sanders (2001), German soldiers constituted a substantial share of the black market, sending purchased goods back to Germany.

${ }^{20}$ At the end of 1942 Pierre Laval informed the German Foreign Minister van Ribbentrop that the black market for agricultural and industrial goods represented 15 and 10 percent of all economic activity. (Sanders, 2001).
} 
relatively poor economic performance of the late 1930s. Figure 2 displays the asset side of the economy, with the rapid rise in real debt and money.

\section{Figure 2}
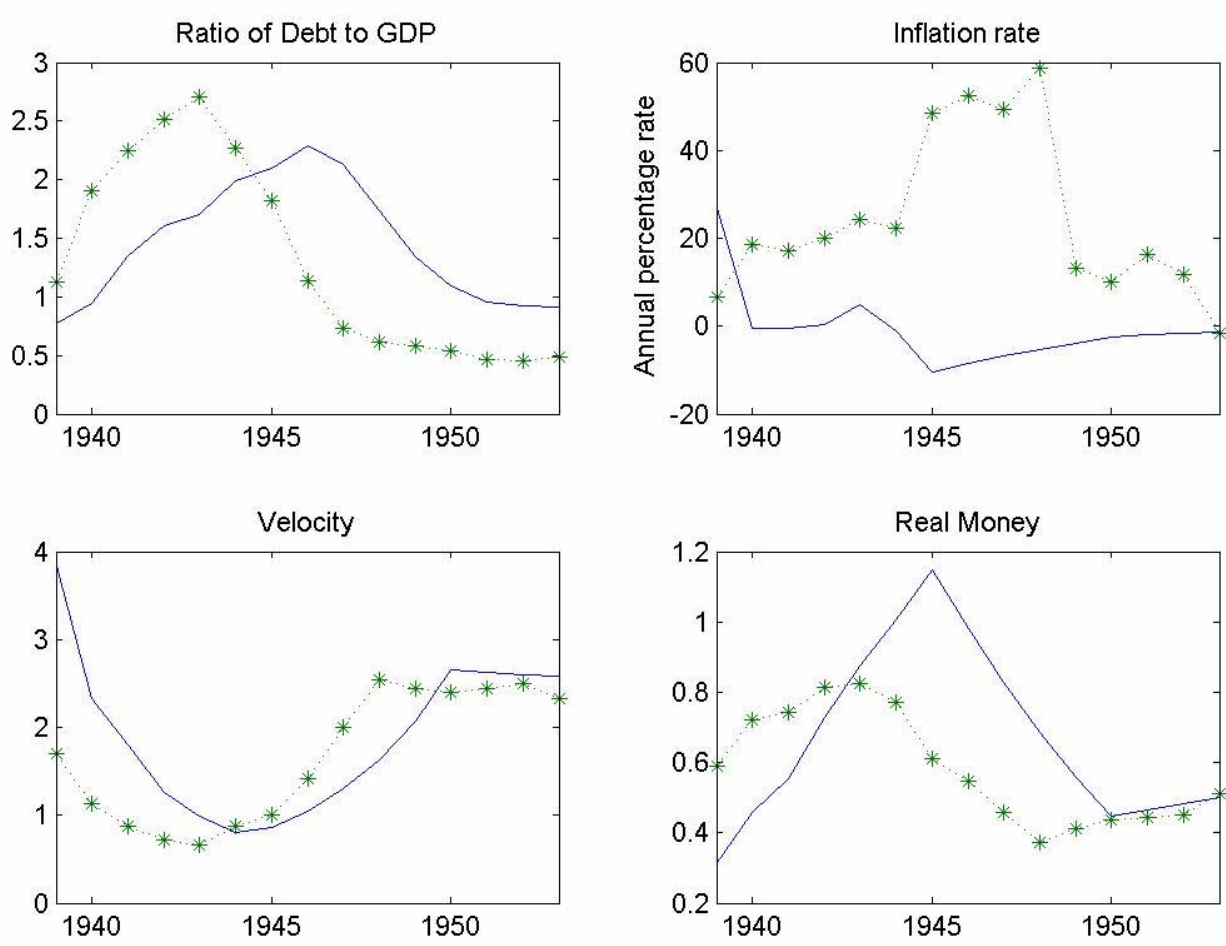

During the war the debt to income ratio and real money climbed as part of the efforts of Vichy to finance the war, and our estimated paths for these variables roughly followed their observed trajectories. Their closeness is perhaps surprising since our model has a non-distortionary stabilization program in contrast to the postwar inflationary policies. In these figures, inflation weakly mimics its actual movement, with the calibrated average inflation rate below the observed rate. The average calibrated rate for 1939-1944 was 5.1 percent well below the average observed rate of 18.2 percent for retail prices. The differential becomes even larger after 1944 when postwar governments resorted to inflation, a feature which will be discussed later.

How closely does our baseline model approximate the structure of Vichy war finance? Table 6 reports the shares of government revenue derived from taxes, bond revenue, and seigniorage for the model depicted in Figures 1 and 2. The shares generated by the model are fairly close to the actual shares. The primary difference is that actual 
seigniorage was produced by faster inflation and money growth than witnessed in the model.

Table 6

Actual and Counterfactual Shares of Government Finance (percent)

\begin{tabular}{|l|l|l|l|l|l|l|}
\hline & $\begin{array}{l}\text { Actual } \\
\text { Taxes }\end{array}$ & $\begin{array}{l}\text { Actual } \\
\text { Debt }\end{array}$ & $\begin{array}{l}\text { Actual } \\
\text { Money }\end{array}$ & $\begin{array}{l}\text { Model } \\
\text { Taxes }\end{array}$ & $\begin{array}{l}\text { Model } \\
\text { Debt }\end{array}$ & $\begin{array}{l}\text { Model } \\
\text { Money }\end{array}$ \\
\hline 1940 & 25 & 27 & 44 & 26 & 58 & 16 \\
\hline 1941 & 30 & 34 & 34 & 35 & 28 & 37 \\
\hline 1942 & 36 & 26 & 40 & 40 & 16 & 44 \\
\hline 1943 & 30 & 35 & 37 & 51 & 23 & 26 \\
\hline 1944 & 30 & 52 & 15 & 33 & 62 & 5 \\
\hline
\end{tabular}

Wartime finance produced a large accumulated debt that required postwar policies that would substantially deviate from the steady state. The five year program of lump sum taxes that were needed to bring the end-of-war debt down to the sustainable debt to GDP level was equal to 97 percent of steady state GDP. ${ }^{21}$ The graph for the debt to income ratio in Figure 2 shows the actual data with the starred line and our model's results, including the stabilization, with the solid line. Although the timing of the rise and fall in this ratio is missed, we approximate its movements. The actual path shows a huge fall in the ratio during the politically unstable postwar period, when inflation surged, reducing the real value of the debt. This huge effective default lowered the ratio to 0.53 in 1950, well below the steady state level of 0.864 . The rise in real money balances is roughly tracked in Figure 2, though we have a higher end-of-war level because there is less inflation in our model. We do capture the behavior of velocity, and the higher real money combined with lower inflation produces realistic levels of seigniorage reported in Table 6.

We calculate the welfare cost as the additional permanent annual consumption that would make up the difference between the wartime consumption and the steady state economy over a twenty year period. ${ }^{22}$ The total annual cost of the wartime policies independent of the stabilization package would have been 19.96 percent of

\footnotetext{
${ }^{21}$ It is equal to 124 percent of 1945 GDP, however this year had a very depressed economy in the immediate aftermath of the war.

${ }^{22}$ Although we could have chosen an infinite horizon, we selected twenty years instead as representing the maximum time horizon of any politician.
} 
consumption. ${ }^{23}$ The relative costs of the separate policies can be seen in Table 7 for the Baseline Model with a non-distortionary stabilization program. A central question faced by the Nazis was whether to deploy French labor in France or in Germany. They kept a large number of soldiers as POWs; and ultimately, they drafted French workers across the Rhine. If all the variables are set at their steady state levels, and only the imposition on the French economy was the retention of POWs and the labor draft to Germany, the loss were be 3.08 percent of consumption. The additional labor would have made a major improvement to the productive capacity of the economy and hence reduced the loss. Wage and price controls produced a lost of 2.46 percent. By far the largest factor was the government spending and occupation payments, which cost the economy 16.27 percent. The remaining individual effects are relatively small by comparison. Money growth has the "wrong" sign because calibrated inflation was not sufficient to produce a fall in real balances that would lower utility. However, it should be noted that real balances increased until 1944, largely a result of financial repression. The components almost but do not add up to the total, reflecting the interaction of these distortions on the economy.

\section{Table 7}

Welfare Cost of Separate Policies (percent)

\begin{tabular}{|l|r|}
\hline \multicolumn{1}{|c|}{ Loss } & $\begin{array}{c}\text { Baseline } \\
\text { Model }\end{array}$ \\
\hline POWs and Labor Draft & 3.08 \\
\hline Wage and Price Controls & 2.46 \\
\hline Government Spending & 16.27 \\
\hline Increased Taxation & 1.09 \\
\hline Net Exports & -0.57 \\
\hline Money Growth & -1.04 \\
\hline Total Cost & 19.96 \\
\hline
\end{tabular}

Any wartime government had good economic reason to shift the burden over a long period of time. Modern nations rarely use taxes exclusively, although the U.S. depended heavily on taxation during the Korean War, with a resulting high cost (Ohanian, 1997). Vichy used formal and informal regulation to induce individuals and institutions to hold more government bonds. Higher taxes and less borrowing could have reduced the size of the postwar adjustment but at a considerable cost. Vichy's average

\footnotetext{
${ }^{23}$ These costs will vary with the time horizon. For five years, the welfare cost was 53.7, for 100 years 8.2 , and for an infinite time horizon, 7.1 percent.
} 
tax rates during the war for labor and capital peaked at 16 and nearly 60 percent during the war. If only taxes were increased and the rest of the wartime policies retained, there is no set of tax rates that can completely avoid the need for some stabilization, as shown in Table 8. As tax rates increase, the tax base begins to shrink so that total tax revenue exhibits a Laffer curve, first increasing and decreasing. If both factors were taxed at 40 percent throughout the war, the required stabilization program would have been 31 percent of steady state GDP. At 50 percent, it would have been 15 percent, with the minimal stabilization program occurring at 57 percent tax rates, yielding 11 percent of steady state GDP; after this point the size of the postwar program and the welfare cost climb. The reason why heavier wartime taxation was not adopted is obvious: the welfare cost is 30.7 percent of consumption or a 50 percent addition to the wartime costs of 19.9 percent.

Table 8

Higher Wartime Taxes

\begin{tabular}{|c|c|c|c|c|c|c|c|}
\hline Tax Rates on Labor and Capital & 20 & 30 & 40 & 50 & 57 & 60 & 70 \\
\hline $\begin{array}{c}\text { Size of Stabilization } \\
\text { (relative to Steady State GDP) }\end{array}$ & 1.01 & $\mathbf{0 . 6 0}$ & $\mathbf{0 . 3 1}$ & $\mathbf{0 . 1 5}$ & .11 & $\mathbf{0 . 1 2}$ & $\mathbf{0 . 2 4}$ \\
\hline Welfare Cost (20 years) & 20.1 & 21.8 & 24.3 & 27.7 & 30.7 & 32.2 & 38.3 \\
\hline
\end{tabular}

What we have produced is a fairly close replication of the behavior of the French economy under German occupation. The cost borne by France was extraordinarily high; and to these wartime costs must be added the cost of a stabilization policy that would return the economy to its stationary debt to GDP ratio. The natural question is how Vichy intended to manage this burden and what were the choices faced by the post-1944 governments.

\section{Postwar Stabilization}

Before examining the issue of postwar stabilization, the question of what the public and policy makers expected at the outset of occupation needs to be addressed given that we are employing a perfect foresight model but are dealing with the uncertainties of war. Most historical accounts agree that in 1940, defeated France was demoralized and accepted the apparent new European order. A reasonable assumption is that they believed that Germany would "win" by the end of 1942. Evidence from the Vichy bond market (Oosterlinck, 2003) reveals that the investing public apparently 
accepted that Hitler would be victorious. Until early 1943, the 3 percent rentes issued by the Third Republic and bonds of comparable maturity issued by Vichy traded at similar prices; when the possibility of defeat and potential repudiation of Vichy debt arose later, a premium was commanded by the older rentes, which any government of Liberation was more certain to honor. Furthermore, up until the end of 1942, total short and medium term debt was less than half of total debt. The government appeared to be confident that it could sell long-term debt at low nominal yields. After this time, shorter term debt became more important than long term debt and stood at 60 percent of all debt by August 1944 (Mitzakis, 1945). Thus, it appears that until early 1943, the public believed that Hitler would succeed, conquering the Russians and obtaining a peace treaty from Britain.

\section{Figure 3}
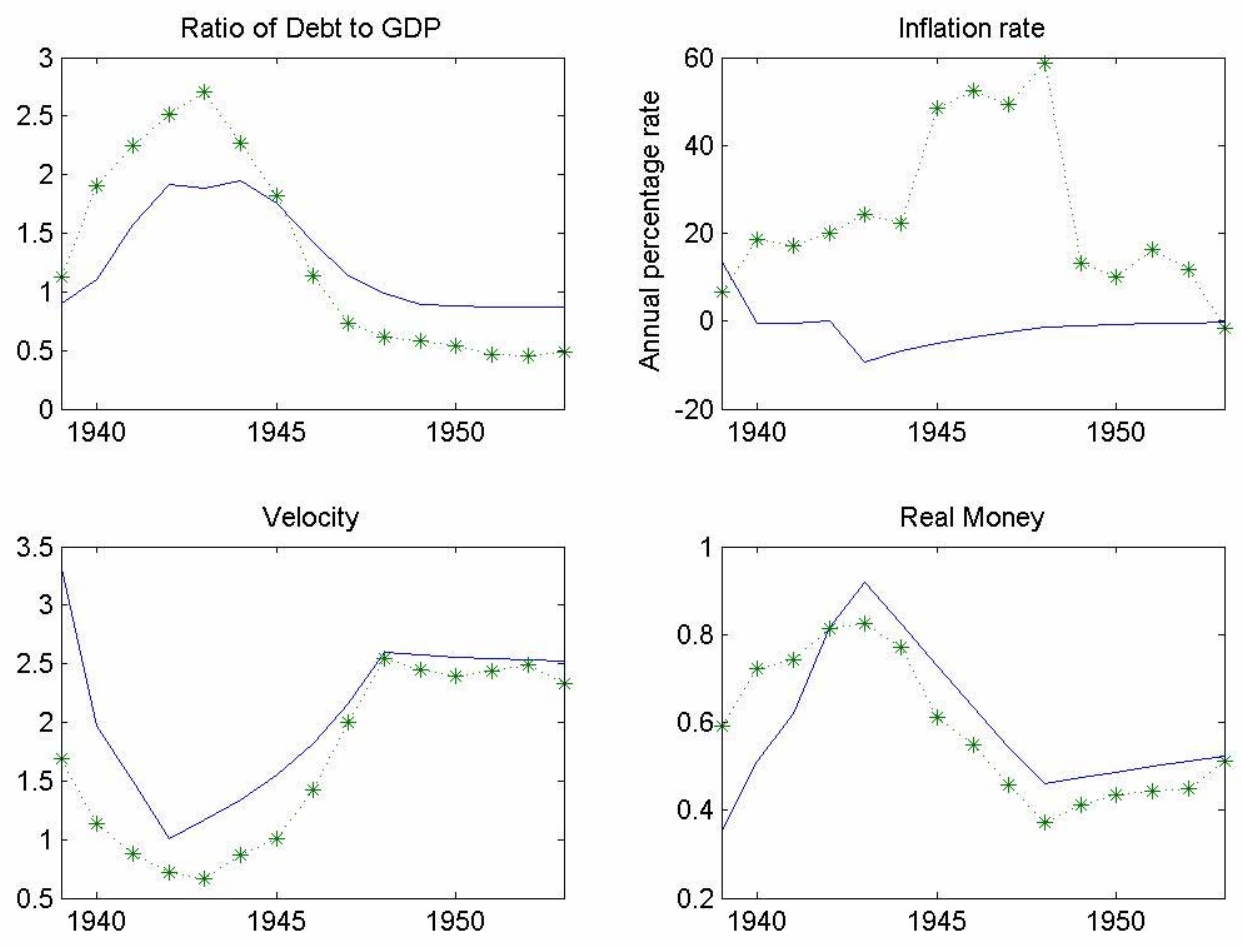

Even with this favorable scenario, which assumes that German demands on the French economy ceased with victory at the end of 1942, there is a huge postwar burden. Figure 3 shows the asset markets' predicted behavior for this shorter war. The welfare cost of the war ending in 1942 is lower, the equivalent of a 12.85 percent twenty year annual reduction in consumption, an improvement over the 19.96 percent cost for the four year war but still very high. However, the size of the requisite five year fiscal 
stabilization package would be 88 percent of steady state GDP, not much lower than the 97 percent for the four year war. In terms of financing the shorter war, the patterns of debt to GDP and real money in Figure 3 more closely match the magnitude and timing of the actual paths of these variables, suggesting that the public believed this be the actual outcome, only to be surprised later. Nevertheless, Vichy was unable to significantly reduce its postwar burden during a shorter war because the model predicts that it would continue to rely on debt finance. In the years 1940-1942, 57, 26 and 59 percent of expenditures would have been financed by debt producing the need for a large stabilization package.

Given the apparent inability of escaping from the heavy postwar burden with a shorter war, we will focus our analysis on the four year war model to address the question of how the postwar debt and money overhang would have been handled by Vichy and the governments of Liberated France. In Nazi Europe, Vichy France would have remained a vassal state. We assume that at the war's conclusion in 1944, occupation payments ceased. Trade would have been very limited and the debt would have been managed internally without access to external capital markets. Debt and monetary overhangs would have been eliminated by running budget surpluses. In essence, we assume that Vichy followed a very nineteenth century remedy of raising taxes over a long period in order to slowly pay down the debt to its steady state level. The various tax policies are shown in Table 9, starting with 11 percent, the steady state rate. Moving back to tax rates of 11 percent in 1945 would have caused the requisite stabilization package explode to 372 percent of steady state GDP after 20 years. The welfare cost remains the same because the stabilization of this vast sum is carried out with a non-distortionary tax. Raising tax rates to 20 percent would still leave a large stabilization after twenty years; but at 30 percent tax rates for two decades, the debt would be reduced to its steady state level. The total welfare cost of this potential policy is 26.9 percent of annual consumption, with the cost of the wartime policies representing 19.9 percent and stabilization an additional 7.0 percent of consumption. While this is a substantial loss, it is significantly less than the consumption loss that would have been incurred if wartime tax rates had been increased to their maximum. 
Table 9

A Hypothetical Vichy Postwar Stabilization Program

\begin{tabular}{|c|c|c|c|c|}
\hline $\begin{array}{c}\text { 20 Year Tax Rates on } \\
\text { Labor and Capital }\end{array}$ & 11 & 20 & 30 & 40 \\
\hline $\begin{array}{c}\text { Size of Stabilization } \\
\text { (relative to GDP) }\end{array}$ & 3.72 & 1.65 & -0.03 & -1.12 \\
\hline Welfare Cost & 19.9 & 22.5 & 26.9 & 32.9 \\
\hline
\end{tabular}

Post-World War II tax rates were, in fact, dramatically higher on labor and capital than in the Belle Epoque or the best years of the Interwar period. In 1947, the tax rates were 22 and 20 percent; and by 1950 they were 31 percent on labor and 27 percent on capital. These would have been sufficient to finance the accumulated debt except that government expenditure was much higher than the steady state and represented more than 30 percent of GDP by 1950 . Not only were there higher expenditures derived from the war, but the modern welfare state was expanding. No surplus was generated until 1959; higher revenues covered higher current expenditures. Our model of Vichy's behavior treats it as a backward-looking regime that would not have embraced the modern welfare state.

The stabilization policies of liberated France followed a very different path. Immediately after the war, the government became heavily dependent on inflationary finance (Eichengreen and Casella, 1994). The government briefly tried to halt rising inflation with price controls in 1947, but shortages and an expanding black market brought it to an end. At the beginning of 1948, the government imposed a one-time tax on monetary assets that raised 150 billion francs, put credit controls in place, cut expenditures, and impounded all 5,000 franc notes to punish the black market (yielding 300 billion francs). While these actions temporarily held inflation in check by providing the Treasury with revenue and reducing the money stock, inflation rose rapidly in the second half of the year. Inflation, which ranged between 40 and 60 percent in the immediate postwar years, was then brought down to 1.4 percent in 1949 and 2 percent in 1950. The brief but very rapid postwar inflation contributed to the reduction of the debt overhang. From 181 percent of GDP in 1944, debt fell to 65 percent in 1947 and 51 percent by 1950 .

The Marshall Plan was another factor contributing to stabilization. Between April 1948 and March 1952, the U.S. provided France with \$2.4 billion of European Recovery 
Program funds under the Marshall Plan. This funding equaled 11 percent of France's 1948 GDP, and it financed about a quarter of the French budget deficit in 1948 and half in 1949. The Marshal Plan funds were given in the form of grants of goods and services, conditional on the recipient countries presentation of acceptable budgets and programs. The French government then sold the imported goods to domestic business in exchange for francs. According to Casella and Eichengreen (1994), the Marshall Plan funds were most important for solving the distributional conflicts and securing agreement among the parties in the French government. The Marshall Plan assisted with the financing of the balance of payments deficit, which had been covered by substantial foreign credits. In 1944 and 1945, Switzerland and Britain provided trade credits as did the Export-Import Bank for a total of $\$ 550$ million. In the next two years, France financed about half of its trade deficit by exhausting its gold and foreign exchange reserves and by requisitioning French-held foreign securities. The American Treasury and to a lesser extent the governments of Canada and New Zealand, the International Monetary Fund and the World Bank provided the remainder, for a total of nearly 7 percent of French GNP (Patat and Lutfalla, 1990). Arriving in late 1948, the Marshall Plan may have helped to close the budget deficit and eliminate the need for the government to go to the Banque de France for advances, but it seems less likely to have contributed to the drop in the debt to GDP ratio, which had fallen to 45 percent in that year from 247 percent in $1945 .^{24}$

To measure the cost of actual postwar policies, we examine the results of French policies before and after the Marshall Plan, dividing the immediate postwar period into 1945-1947 and 1948-1951. Table 10 explores the postwar policies, with the baseline model providing the measure of wartime costs. Although there were brief periods of controls, we assume that markets became free following the demise of the wartime wage and price controls and the return of drafted labor; and we use the observed tax rates, government expenditures, money growth, and net exports to examine the welfare costs.

By the end of 1947, before the Marshall Plan took effect, the total welfare cost of wartime policies and stabilization shows a decline from 19.96 to 16.03 percent---not an increase as Vichy tax policy would have produced. Higher taxes added to the cost, but money growth and net exports reduced it. Money growth in our model does not generate

\footnotetext{
${ }^{24}$ In a simple calculation, if there were no growth or Marshall Plan, inflation alone would have reduced the debt to GDP ratio to 102 percent by 1948; growth alone with no inflation or Marshall Plan would lowered the ratio to 162 percent, while the Marshall Plan produced a 3 percent decline.
} 
enough inflation to reduce real balances, which would generate additional costs. For purposes of this discussion we treat postwar inflation as unexpected, thus approximating a lump-sum tax with no augmentation of the welfare cost. More importantly, even in the absence of this factor, total welfare cost would have declined because of net exports. The international trade credits, described above, permitted France to run a huge trade deficit. For simplicity in this calculation, we treat these long-term, low-interest intergovernmental credits as gifts, giving a slight upward bias to our estimate of the benefit. The next column, where there were no trade credits and France would have been forced to balance trade after the war, simply shows that the trade credits improve welfare by about four percent by 1947 . The debt to GDP ratio had been reduced by inflation to 45 percent; and what effectively was accomplished was the substitution of domestic debt for some foreign debt that eased the consumption constraint, moving government finance closer to the optimum where foreign transfers would have been financed by long-term foreign borrowing.

Table 10

Postwar Stabilization (percent)

\begin{tabular}{|l|r|r|r|r|r|r|}
\hline \multicolumn{1}{|c|}{ Loss } & $\begin{array}{c}\text { Baseline } \\
\text { Model }\end{array}$ & $\begin{array}{c}\text { Actual } \\
\text { To 1947 }\end{array}$ & $\begin{array}{c}\text { No Aid } \\
\text { To 1947 }\end{array}$ & $\begin{array}{r}\text { Actual } \\
\text { To 1951 }\end{array}$ & $\begin{array}{c}\text { No Aid } \\
\text { To 1951 }\end{array}$ & $\begin{array}{c}\text { Marshall } \\
\text { Plan Effect }\end{array}$ \\
\hline POWs and Relève & 3.08 & 3.08 & 3.08 & 3.08 & 3.08 & 3.08 \\
\hline Wage and Price Controls & 2.46 & 2.46 & 2.46 & 2.46 & 2.46 & 2.46 \\
\hline Government Spending & 16.27 & 16.27 & 16.27 & 16.27 & 16.27 & 16.27 \\
\hline Increased Taxation & 1.09 & 1.59 & 1.59 & 2.35 & 2.35 & 2.35 \\
\hline Net Exports & -0.57 & -4.72 & -0.57 & -5.69 & -0.57 & -4.99 \\
\hline Money Growth & -1.04 & -1.77 & -1.77 & -2.89 & -2.89 & -2.89 \\
\hline Total Cost & 19.96 & 16.03 & 19.90 & 14.96 & 19.71 & 15.56 \\
\hline
\end{tabular}

Considering the whole of the stabilization period to the end of 1951 when inflation ceased and the Marshall Plan was completed, there is some higher welfare cost from increased taxation, but it is overwhelmed by the higher net imports financed by more trade credits and American aid, reducing the welfare cost by 5.12 percent (5.690.57). The last column shows only trade credits and no Marshall Plan and reveals that the program lowered the consumption loss by about half a percent (5.69-4.99), a fraction of the benefit from the trade credits. Again, the acceptance of foreign debt to overcome the consumption loss derived from the transfers to Germany represented a welfare-improving policy. 
Not only did the policies of liberated France appear to lower the costs of German exactions, but they also had radically different distributional consequences. The struggle over how to balance the budget and ensuing inflation appears to have been too great and too costly as it pushed the debt to GDP ratio below the steady state level of 86.4 percent of GDP. The inflation produced capital losses for the owners of government debt. Although apparently little is known about the ownership of the debt, among the largest holders of debt were the banks and other financial institutions, who under the regime of financial repression had been induced to expand their bond holdings. In 1939, the largest deposit bank, Crédit Lyonnais held 44 percent of its investments and 18 percent of its assets in short-bonds. By 1942, these bonds accounted for 85 percent of its portfolio and 37 percent of its assets (Plessis and Verheyde, 2003). Part of this expansion of bond holdings by the banks was facilitated by issues of new shares, which in the case of Crédit Lyonnais more than doubled its capital but which barely kept its capital to asset ratio hovering below 5 percent. The post-inflation market values of the debt would have threatened the solvency of these institutions. In this light, the 1945 nationalization of the four largest deposit banks appears to have been dictated by insolvency, rather than the hostility of the government, which saw the banks as passive collaborators.

\section{Conclusion}

Although occupied, Vichy's methods of financing German demands closely resembled "ordinary" war finance by belligerents. Under even the most optimistic scenario that French policy makers could have believed, where the war ended in 1942 and there was an immediate termination of occupation costs, the financing of the transfers to the Nazis imposed a welfare cost equal to a 12.6 percent reduction of consumption for twenty years plus the cost of financing a debt overhang equal to 88 percent of steady state GDP. Actual financing costs in our model left a 19.9 percent reduction in consumption; where the payments directly accounted for 16.7 percent of the cost, followed next in importance by the retention in Germany of POWs and the labor draft that added 3.1 percent. The full four years of war left a debt overhang of 97 percent of GDP.

Where there was a will, even a coerced will, to pay, extraordinary sacrifices were feasible. Assuming that Vichy's postwar plans would have followed its traditionalist pattern, a budget surplus generated by higher taxes could have eliminated the debt overhang in twenty years at an additional cost of 7 percent of consumption. Tax rates did 
actually rise to the requisite levels, but the necessary surplus never appeared because the budget was swollen by reconstruction expenditures and higher peacetime expenditures associated with the nascent welfare state. It is not a great stretch to imagine that the repressive Vichy regime could have managed to raise taxes to rein in the debt if there had been victory in 1942, liberated democratic France could not. The postwar budgetary struggle arose after Liberation yielded an inflation that slashed the real debt. Yet, if this inflation was largely unexpected, then it was relatively low cost with the burden of adjustment falling heavily on those---financial institutions and individuals---who had been induced to buy Vichy's bonds. Finally, the cost of stabilization was lowered by the fact that France could tap international capital markets and could borrow on favorable terms to finance consumption in the critical years of reconstruction that preceded the miracle years of growth. 


\section{Bibliography}

Aly, Götz, The Final Solution: The Nazi Population Problem and the Murder of the Jews (London: Oxford University Press, 2000).

Arnoult, Pierre, "Les finances de la France",in La France sous 1'occupation (Paris :

Presses Universitaires de France, Collection Esprit de la Résistance, 1959), pp.39-56

Banque de France, Assemblée Générale des Actionnaires, Compte Rendu, Paris (Imprimerie Paul Dupont, various years).

Barro, Robert J., "Government Spending, Interest Rates, Prices and Budget Deficits in the United Kingdom," Journal of Monetary Economics 20 (1987), pp. 221-248.

Barro, Robert J., "The Neoclassical Approach to Fiscal Policy," in Robert J. Barro, ed., Modern Business Cycle Theory (Cambridge: Harvard University Press, 1989), pp. 236264.

Bouthillier, Yves, Le drame de Vichy (2 volumes), (Paris, Plon, 1951).

Bordo, Michael, Dominique Simard and Eugene N. White, "France and the Bretton Woods International Monetary System 1960 to 1968," in Jaime Reis, ed., International Monetary Systems in Historical Perspective (St. Martins Press, New York, 1995).

Bettelheim, Charles, Bilan de l'économie française, 1919-1946 (Paris: Presses Universitaires de France, 1947.

Carré, J.-J., P. Dubois and E. Malinvaud, French Economic Growth (Stanford: Stanford University Press, 1975).

Cathala, Pierre, Face aux réalités. La direction des finances françaises sous l'occupation, (Paris, Editions du Triolet, 1948).

Cohen, Daniel, "How to evaluate the solvency of an indebted nation", Economic Policy 16 (1985), pp. 140-167.

Dormais, Jean-Pierre, The French Economy in the Twentieth Century (Cambridge: Cambridge University Press, 2004).

Du Parquet, L, "Le financement français de la première guerre mondiale," Comité pour l'Histoire Economique et Financière de la France, Histoire des Marchés Financiers (Paris, forthcoming 2006).

Ferguson, Niall, The Pity of War (Great Britain: Penguin Press, 1998).

Fisk, Harvey E., French Public Finance in the Great War and Today (New York: Bankers Trust Company, 1922). 
France. Archives Nationales (Paris). Fonds AJ40, (1939-1945), Vol. 832.

Friedman, Milton, "Price, Income and Monetary Changes in Three Wartime Periods," American Economic Review 42 (May 1952).

Friedman, Milton and Anna J. Schwartz, A Monetary History of the United States, 18641960 (Princeton: Princeton University Press, 1963).

Goldin, Claudia D., "War" in Glann Porter, ed., Encyclopedia of American Economic History Vol. III, (New York: Charles Scribner's Sons, 1980), pp. 935-957.

Herbert, Ulrich, Hitler's foreign workers. Enforced labor in Germany under the Third

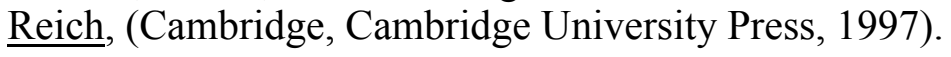

Institut National de la Statistique et des Études Économiques (INSEE), Annuaire Statistique de la France Résumé Rétrospectif (Paris, 1966).

Les Institutions de la France nouvelle, V Finances et droit fiscal (juillet 1940 mars 1942), (Paris : Société d'éditions économiques et sociales, 1942).

Klug, Adam, "The Theory and Practice of Reparations and American Loans to Germany, 1925-1929," (Princeton: Working Papers in International Economics, G-90-03, International Finance Section, 1990).

Liberman, Peter, Does Conquest Pay? (Princeton: Princeton University Press, 1996).

Ljunqvist, Lars, and Thomas J. Sargent, Recursive Macroeconomic Theory $2^{\text {nd }}$ ed., (Cambridge: MIT Press, 2004)

McGrattan, Ellen R. and Lee E. Ohanian, "Does Neoclassical Theory Accout for the Effects of Big Fiscal Shocks? Evidence from World War II" (Federal Reserve Bank of Minneapolis, Research Department Staff Report 315), January 2003.

Makinen, Gail E., and G. Thomas Woodward, "Funding crises in the aftermath of World War I," in Rudiger Dornbush and Mario Draghi, Public debt management: theory and history (Cambridge: Cambridge University Press, 1990).

Mankiw, N. Gregory, "The Optimal Collection of Seigniorage: Theory and Evidence," Journal of Monetary Economics (1987), 20, pp. 327-41.

Margairaz, Michel, and Bloch-Lainé, François, L'Etat, les finances et l'économie histoire d'une conversion 1932-1952 (Paris: Comité pour l'histoire économique et financière de la France, 1991).

Margairaz, Michel, "La Banque de France et l'Occupation," in Michel Margairaz, ed., Banques, Banque de France et Seconde Guerre Mondiale (Paris: Albin Michel, 2002), pp-15-37-84. 
Merigot, J-G. and Coulbois P., Le Franc, 1938-1950 (Paris: Librairie Générale de Droit et de Jurisprudence, 1950).

Milward, Alan S., The New Order and the French Economy (Oxford: Clarendon Press, 1970).

Mitzakis Michel, Principaux aspects de l'évolution financière de la France 1936-1944, Paris, Les Publications Techniques, 1945).

Neal, Larry, "The Economics and Finance of Bilateral Clearing Agreements: Germany, 1934-8," Economic History Review Second Series, Vol. XXXII, No. 3 (August 1979), pp. 391-404.

Nogaro, Bertrand, Le financement des dépenses publiques et la liquidation des dépenses de guerre (Paris: Domat-Montchrestien, 1945).

Obstfeld, M and Rogoff, K., "The intertemporal approach to the current account," in G. M. Grossman and K. Rogoff, eds., Handbook of International Economics Vol. III. (New York: Elsevier, 1995).

Ohanian, Lee E., "The Macroeconomic Effects of War Finance in the United States: World War II and the Korean War," American Economic Review 87, 1 (March 1997), pp. 23-40.

Oosterlinck, K. "The Bond Market and the Legitimacy of Vichy France," Explorations in Economic History 40:3 (2003), pp. 327-345.

Patat, Jean-Pierre and Michel Lutfalla, A Monetary History of France in the Twentieth Century (New York: St. Martins Press, 1990).

Piketty, Thomas, "Income Inequality in France, 1901-98," Centre for Economic Policy Research, Discussion Paper No. 2876 (July 2001).

Piketty, Thomas, Les hauts revenus en France au $\mathrm{XX}^{\mathrm{e}}$ siècle: Inégalités et redistributions, 1901-1998 (Paris, Editions Grasset, 2001).

Plessis, Alain, "Les grandes banques dépôts et l'Occupation," in Michel Margairaz, ed., Banques, Banque de France et Seconde Guerre Mondiale (Paris: Albin Michel, 2002), pp-15-36.

Plessis, Alain and Philippe Verheyde, "Le Crédit lyonnais sous l'Occupation," in Bernard Desjardins, Le Crédit Lyonnais (Geneva : Droz, 2003, pp. 889-951.

Rebelo, Sergio, « Real Business Cycle Models : Past, Present, and Future, » (NBER Working Paper 11401, June 2005). 
Rockoff, Hugh, "Prices and Wage Controls in Four Wartime Periods," Journal of Economic History 41, 2 (June 1981), pp. 381-401.

Sanders, Paul, Histoire du marché noir 1940-1946, (Paris, Perrin, 2001).

Schuker, Stephen A, American 'reparations' to Germany 1919-1933: implications for the Third-World debt crisis, (Princeton: Princeton Studies in International Finance, No. 61, 1988).

Sédillot, René, Histoire des marchés noirs (Paris: Tallandier, 1985).

Toutain, Jean-Claude, "Le produit intérieur brut de la France, 1789-1990," Economies et Sociétés, Histoire économique quantitative, Série HBQ (1997), pp. 5-136.

Walsh, Carl E., Monetary Theory and Policy (Cambridge: MIT Press, 2003).

White, Eugene N., "Making the French pay: The costs and consequences of the Napoleonic reparations," European Review of Economic History 5 (2001), pp. 337-365. 